\title{
Antibacterial activity of Syzigium cumini leaf extracts against multidrug resistant pathogenic bacteria
}

\author{
Mohammed Imran, Mohd. Imran ${ }^{*}$, Shaista Khan \\ Department of Biosciences, Integral University, Lucknow-226026, U. P., India.
}

\begin{tabular}{|c|c|}
\hline ARTICLE INFO & ABSTRACT \\
\hline $\begin{array}{l}\text { Article history: } \\
\text { Received on: } 08 / 12 / 2016 \\
\text { Accepted on: } 17 / 01 / 2017 \\
\text { Available online: } 30 / 03 / 2017\end{array}$ & $\begin{array}{l}\text { Staphylococcus aureus (MRSA and MSSA) and Escherichia coli strains were isolated from the Clinical } \\
\text { specimens such as pus, wound, urine, ear swabs and blood collected from the Health care centers at Lucknow } \\
\text { city of Northern India. All strains were tested and detected as multi-drug resistant against penicillin, ampicillin, } \\
\text { cefpdoxime, sulphadiazine, nalidixic acid, erythromycin and amoxicillin. Antibacterial activity of Syzigium }\end{array}$ \\
\hline $\begin{array}{l}\text { Key words: } \\
\text { Syzigium cumini, } \\
\text { antibacterial activity, Clinical } \\
\text { Specimens, Staphylococcus } \\
\text { aureus, Escherichia coli, } \\
\text { Northern India. }\end{array}$ & $\begin{array}{l}\text { petroleum ether and ethanolic solvents with the inhibition zone } 8-24 \mathrm{~mm} \text { than all other solvent extracts tested. } \\
\text { Extracts of Syzigium cumini exhibited prominent activity against both the drug resistant strains of } S \text {. aureus and } \\
\text { E. coli. Minimum inhibitory and minimum bactericidal concentrations of Syzigium cumini leaf extracts were } \\
\text { also determined among the strains. MIC and MBC values varied from } 1.56 \text { to } 25 \mathrm{mg} / \mathrm{ml} \text { and } 1.56 \text { to } 50 \mathrm{mg} / \mathrm{ml} \\
\text { among the tested strains. The combination of ampicillin with plant extracts exhibited a significant synergistic } \\
\text { effects on growth of multidrug resistant strains of both genus tested. Our study thus suggests the use of this } \\
\text { medicinal plant in the treatment of various diseases caused by drug resistant species of } S \text {. aureus and } \text { E. coli. }\end{array}$ \\
\hline
\end{tabular}

\section{INTRODUCTION}

The overuse of antibiotics in the treatment of infections has become the global concern for continuous increase in the emergence and spread of multidrug resistant pathogenic strains (Harbottle, 2006). Nowadays most of the antibiotics have become inactive against some pathogenic microbes like methicillin-resistant $S$. aureus, vancomycin-resistant enterococci, multidrug-resistant Gram negative bacteria, etc. An increase in the emergence of multiple drug- resistant bacteria is threatening the world population. Bacterial resistance to antibiotics increases mortality likelihood of hospitalization and length of stay in the hospital. In general, bacteria have the genetic ability to transmit

\footnotetext{
* Corresponding Author

Dr. Mohd. Imran, Assistant Professor Department of Biosciences Integral University, Lucknow-226026, U. P., India Mobile. No8174061004, Fax: +91-522-2890809,E-mail: imranm@iul.ac.in
}

and acquire resistance to drugs, which are utilized as therapeutic agent (Gislene, 2000). Resistance to antibiotics is one of the greatest threats to the success of modern medicine. The worldwide emergence of Escherichia coli, Klebsiella pneumoniae, Haemophilus and many other B-lactamase producers has become a major therapeutic problem. Multi-drug resistant strains of E. coli are widely distributed in hospitals and are increasingly being isolated from community acquired infections (Khan, 2004; Akram 2007).

Multidrug resistance in clinical bacteria like Staphylococcus aureus is responsible for nosocomial infections (Mulligan et al., 1993). The steadily increasing bacterial resistance to existing drugs is a serious problem, and therefore there is a direct need to search for new classes of antibacterial substances, especially from natural sources. Unlike synthetic drugs, antimicrobials of plant origin are not associated with side effects and have a great therapeutic potential to heal many infectious diseases (Chanda et al., 2010; Habbal et al., 2011). 
Medicinal plants like, Allium sativum, Azadirachta indica, Cordia dichotoma, Holoptelea integrifolia, Ocimum sanctum, Syzigium cumini and Trigonella foenum graecum etc. have been reported to possess antibacterial properties (Ahmad et al., 1998). Medicinal plants contain antibacterial agents to combat infections and their products are used either internally or externally to heal wounds and other injuries and they are used in relieving pain or cure of common diseases such as diabetes, heart disorders and various cancers (Mohanta et al., 2003). Syzigium cumini has been widely used for the treatment of various diseases in traditional and folk medicine (Figure 1). The leaves have antibacterial property and used to strengthen the teeth and gums. The leaves have also been extensively used to treat diabetes, constipation, leucorrhoea, stomachalgia, fever, gastropathy, dermopathy and to inhibit blood discharge in the feces (Gowri and Vasantha, 2010). For this reason, researchers are increasingly turning their attention to herbal products such as Syzigium cumini, looking for new leads to develop better drugs against MDR microbe strains (Braga et al., 2005). In the present study; we have selected Indian medicinal plant Syzigium cumini to be screened against multi-drug resistant bacteria. The selection of medicinal plants is based on its traditional uses in India. (Chopra et al., 1992; Ahmad et al., 1998; Mehmood et al., 1999). The objective of this study was to determine the antibacterial effect of extracts from the Syzigium cumini leaves against multi-drug resistant Escherichia coli and Staphylococcus aureus strains.

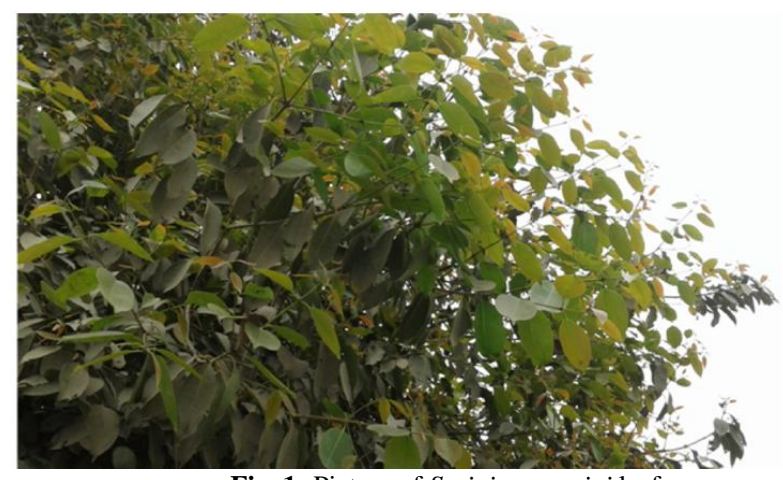

Fig. 1: Picture of Syzigium cumini leaf.

\section{MATERIALS AND METHODS}

\section{Isolation and identification of bacterial strains}

Two bacterial species viz., Escherichia coli and Staphylococcus aureus (MRSA and MSSA) were used in antibacterial assay. These bacterial strains were isolated from the Clinical specimens consisting of pus, wound, urine, ear swabs and blood collected from the Central Pathology Laboratory of Era's Lucknow Medical College and Hospital and Integral Institute of Medical Sciences and Research, Lucknow. The specimens collected were directly streaked onto mannitol salt agar media and EMB agar media specific for each bacterium. The plates were incubated at $37{ }^{\circ} \mathrm{C}$ for 24 hours. The bacterial strains were identified on the basis of cultural, morphological and biochemical tests such as catalase, coagulase, gelatin liquefaction, oxidase,
Triple Sugar Iron agar (TSI), citrate utilization (Simmon's citrates medium), urease (Christensen's Urea Agar), indole, motility, $\mathrm{H}_{2} \mathrm{~S}$ production (Sulphide Indole Motility Medium) and sugar fermentation tests. Staphylococcus aureus reference strain MTCC 96 and Escherichia coli reference strain MTCC 443 were obtained from IMTECH, Chandigarh. All culture media were provided by Himedia Laboratories Pvt. Ltd., India.

\section{Determination of antimicrobial resistance}

Pure isolates of identified Staphylococcus aureus and Escherichia coli were subjected to antimicrobial susceptibility testing using the disc diffusion method as recommended by Kirby Bauer method according to the recommendations of Clinical Laboratory Standard Institute (CLSI, 2010), formerly National Committee for Clinical Laboratory Standards (NCCLS) (2002), using the following antibiotics discs obtained from Hi-Media Laboratories Pvt. Ltd, Mumbai: methicillin (MET) $5 \mu \mathrm{g}$, oxacillin (ox)1 $\mu \mathrm{g}$, penicillin G (PEN) $10 \mathrm{IU}$, erythromycin (ERYTHRO) 5 $\mu \mathrm{g}$, nalidixic acid (NA) $30 \mu \mathrm{g}$, kanamycin (KAN) $30 \mu \mathrm{g}$, nitrofurazone (NR) $100 \mu \mathrm{g}$, tetracycline (TET) $10 \mu \mathrm{g}$, polymyxin $\mathrm{B}$ (PB) $300 \mu \mathrm{g}$, ciprofloxacin (CIP) $5 \mu \mathrm{g}$, ampicillin (AMP) $10 \mu \mathrm{g}$, ofloxacin (OF) $5 \mu \mathrm{g}$, sulphadiazine (SZ) $300 \mu \mathrm{g}$, amoxicillin (AMX) $10 \mu \mathrm{g}$, and cefpodoxime (CPD) $30 \mu \mathrm{g}$, chloramphenicol (CH) $30 \mu \mathrm{g}$, Gentamycin (GEN) $50 \mu \mathrm{g}$, neomycin ( NEO) $30 \mu \mathrm{g}$ and vancomycin (VAN) $30 \mu \mathrm{g}$. All isolates were grown in Brain Hearth Infusion broth and incubated at $37^{\circ} \mathrm{C}$ for $6 \mathrm{~h}$ until the turbidity of $0.5 \mathrm{McFarland}$ standards was achieved. The isolates were then swabbed onto Muller Hinton Agar and allowed to dry for $15 \mathrm{~min}$. The antibiotics discs were placed on the centre of the agar plates with the aid of sterile pointed tip forceps and incubated at $37^{\circ} \mathrm{C}$ for $24 \mathrm{~h}$. The presence of a clear zone around the antibiotic disc is measured with meter rule. $S$. aureus strains were tested for methicillin resistance using the disc diffusion method (Bauer et al., 1966). S. aureus isolates are considered to be resistant to methicillin if the inhibition zones are $<10 \mathrm{~mm}$ while susceptible if the zones of inhibitions were $\geq 10 \mathrm{~mm}$. These isolates were tested and detected as multi-drug resistant against penicillin, ampicillin, cefpdoxime, sulphadiazine, nalidixic acid, erythromycin and amoxicillin. These strains were maintained on agar slants at $4{ }^{\circ} \mathrm{C}$ for antimicrobial tests. The microorganisms were incubated overnight at $37^{\circ} \mathrm{C}$ in Mueller-Hinton Broth (Oxoid) at pH 7.4.

\section{Collection and authentication of plant materials}

Healthy leaves of Syzigium cumini were collected from Herbal Garden of Faculty of Pharmacy, Integral University, Lucknow and road side of Kursi road, Lucknow and they were identified and authenticated by Dr. Muhammad Arif, Assistant Professor, Faculty of Pharmacy, Integral University, Lucknow. Voucher specimens were prepared and deposited in the University Herbarium of Pharmacy Department, Integral University, Lucknow, for future reference. The plants were brought to the laboratory and thoroughly washed in running water to remove debris and dust particles and then rinsed using distilled water and finally air dried protected from direct exposure to sun light. 


\section{Preparation of plant extract}

Syzigium cumini leaves were dried in an oven at temperature below $45^{\circ} \mathrm{C}$ for $2-3$ days and coarsely powdered. The powdered Syzigium cumini leaves were extracted successively with petroleum ether, ethyl acetate, acetone, methanol and ethanol to afford corresponding fractions (Dabur et al., 2004). The filtered extract was left to dryness under reduced pressure on rotary evaporator at $40{ }^{\circ} \mathrm{C}$ and stored at $4{ }^{\circ} \mathrm{C}$ for further use.

\section{Phytochemical analysis}

All the extracts were subjected to phytochemical analysis by using standard procedure for the identification of the various phytoconstituents (Parekh and Chandra, 2007).

\section{Antibacterial Assay}

The agar well diffusion method (Perez et al., 1990) as adopted earlier (Ahmed and Beg, 2001) was used. $0.1 \mathrm{ml}$ of diluted inoculums $\left(10^{5} \mathrm{CFU} / \mathrm{ml}\right)$ of test organism was spread on Muller- Hinton agar plates. Wells of $6 \mathrm{~mm}$ diameter was punched into the agar medium and filled with $50 \mu \mathrm{l}$ of Syzigium cumini leaves extract of $100 \mathrm{mg} / \mathrm{ml}$ concentration and solvent blank (DMSO) separately. The plates were incubated for overnight at $37^{\circ} \mathrm{C}$. The antibacterial activity was evaluated by measuring the zone of inhibition against test organism. The antibiotic disc chloramphenicol $(30 \mu \mathrm{g})$ to which strain is sensitive was used in the test system as positive controls and DMSO, solvent taken in study and ampicillin $(10 \mu \mathrm{g})$ to which strains were resistant were used as negative control. Each experiment was performed in triplicate.

\section{Determination of minimum inhibitory concentration (MIC) of plant extracts}

Minimum inhibitory concentration and minimum bactericidal concentration of plant extracts against drug resistant clinical strains was determined by broth micro dilution method, using specific dye (p-iodonitro tetrazolium violet) as an indicator of growth as described by (Eloff et al., 1998). For each test batch control wells were prepared; the positive control (antibiotic, Mueller-Hinton broth and test organism) and sterility and negative control (Mueller-Hinton broth and DMSO). The plates were incubated at $37{ }^{\circ} \mathrm{C}$ for $24 \mathrm{~h}$. The bacterial activity in the test wells was detected by adding $40 \mu \mathrm{L}$ of $0.2 \mathrm{mg} / \mathrm{ml}$ of specific dye (piodonitro tetrazolium violet) (Himedia, India) solution dissolved in sterile distilled water to each well. The plates were incubated for further $30 \mathrm{~min}$, and observed visually for any change in color to pink indicating reduction of the dye due to bacterial growth. The lowest concentration (highest dilution) of the plant extract required to inhibit visible growth of the tested microorganism was designated as the MIC.

\section{Data Analysis}

All data were measured average value of three replicates and standard error $( \pm)$. Results were subjected to Microsoft excel 2010. $\mathrm{p}<0.05$ was statistically significant.

\section{RESULTS AND DISCUSSION}

The extractive yield of Syzigium cumini leaves using different solvents was determined. Maximum extractive yield was recorded in petroleum ether extract followed by ethanol extract. The extraction ability of different solvents from leaves for recovering extractable components followed the order: petroleum ether $(5.55 \%)>$ ethanol $(3.23 \%)>$ methanol $(2.28 \%)>$ acetone $(1.98 \%)>$ ethyl acetate $(1.66 \%)$. Alcohol and acetone both are polar solvents but alcohol had more extractive yield than acetone. Non polar solvent petroleum ether had more extractive yield than polar solvent alcohol and acetone while semi polar solvent ethyl acetate had minimum extractive yield. Significant differences of extractive yield among different solvents might be attributed to the varied polarity of the solvents.

The leaf extract of $S$. cumini was evaluated for the presence or absence of diverse phytochemicals. The leaves of $S$. cumini are rich in alkaloids, flavonoids, tannins, saponins, steroids and terpenoids, as shown in Table-1. The leaf methanol extract of $S$. cumini was rich in phenols, saponins, glycosides, flavanoids, alkaloids, steroids, terpenoids, resins and tannins.

Table 1: Phytochemical anaiysis of Syzigium cumini leaf extracts in various solvents.

\begin{tabular}{|c|c|c|c|c|c|}
\hline $\begin{array}{l}\text { Phytochemical } \\
\text { constituents }\end{array}$ & 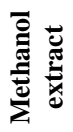 & 预 & 式总 & 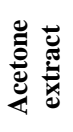 & 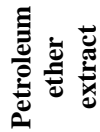 \\
\hline Flavanoids & + & + & - & + & + \\
\hline Alkaloids & + & + & - & + & + \\
\hline Glycosoids & + & + & - & + & - \\
\hline Steroids & + & + & - & + & - \\
\hline Phenol & + & + & - & + & - \\
\hline Tannin & + & - & - & + & - \\
\hline Terpenoids & + & + & - & - & + \\
\hline Saponins & + & + & - & + & - \\
\hline
\end{tabular}

In the present study, Syzigium cumini leaves were extracted with petroleum ether, ethyl acetate, acetone, methanol and ethanol. Antimicrobial potentiality of the extracts was investigated against six strains of Staphylococcus aureus (3 MRSA and 3 MSSA strain) and six strains of Esherichia coli and their potential activity were qualitatively and quantitatively assessed by the presence or absence of inhibition zones and MIC values respectively. Results of the antimicrobial activity obtained using the well diffusion assay is summarized in Table 3. The petroleum ether, acetone and ethanol extracts of the investigated Syzigium cumini leaves showed antimicrobial activities against all tested bacterial strains. All the plant extracts inhibited almost all the bacterial strains with the zone of inhibition ranging from 8-24 mm. Semi polar solvents ethyl acetate showed minimum inhibitory activity $(8-15 \mathrm{~mm})$ and it inhibited 5 clinical strains of $S$. aureus and and 2 clinical strains of $E$. coli and was not effective against SA3 strain and EC10, EC12, EC16, MTCC 443 strains of $S$. aureus and $E$. coli respectively. Maximum inhibitory activity against $S$. aureus was recorded by petroleum ether extract with inhibition zone (22 $\mathrm{mm}$ ) against MRSA strain (SA17). The highest 
antibacterial activity with the zone of inhibition $(24 \mathrm{~mm})$ was seen against EC12 isolates of Escherichia coli strains by ethanol extract of Syzigium cumini leaves. All 5 extracts were compared with 20 standard antibiotics, the results of which are presented in Table 2. The antimicrobial activity of some of the solvent extracts was comparable with that of standard antibiotics. Table 2 illustrates the sensitivity of selected bacterial pathogens towards the standard antibiotics. It was observed that all the pathogens were resistant to the standard antibiotics penicillin, ampicillin, cefpdoxime, sulphadiazine, nalidixic acid, erythromycin and amoxicillin, used in this study. Chloramphenicol was found to be most effective recording its maximum lethal effect against $E$. coli and $S$. aureus strains with $22-28 \mathrm{~mm}$ zones of inhibition. E. coli and $S$. aureus exhibited maximum sensitivity with $26 \mathrm{~mm}$ and $28 \mathrm{~mm}$ against chloramphenicol (C) respectively. All strains of $S$. aureus and $E$. coli were found to be sensitive towards streptomycin (S) recording highest zone of inhibition $22 \mathrm{~mm}$ and all S. aureus strains were sensitive to vancomycin and less sensitive towards polymyxin B (PB) with highest $15 \mathrm{~mm}$ zone of inhibition.

The MIC and MBC values were evaluated against 6 Gram positive bacteria (3 MRSA and 3 MSSA) and 6 Gram negative bacteria (Escherichia coli). The values are presented in Table 4a and 4b. For both Staphylococcus aureus and Escherichia coli strains, MIC and MBC values varied from 1.56 to $25 \mathrm{mg} / \mathrm{ml}$ and 1.56 to $50 \mathrm{mg} / \mathrm{ml}$ respectively. EC10 and MTCC 443 strains of Escherichia coli were the most susceptible gram negative organism to ethanol extract (MIC; $1.56 \mathrm{mg} / \mathrm{ml}$ and MBC; 3.12 $\mathrm{mg} / \mathrm{ml}$ ), and MTCC 96 strain of Staphylococcus aureus were most susceptible to petroleum ether and acetone extract (MIC; 1.56 $\mathrm{mg} / \mathrm{ml}$ and $\mathrm{MBC} ; 3.12 \mathrm{mg} / \mathrm{ml}$ ).

For the standard antibiotics (CH and AMP) MIC and $\mathrm{MBC}$ were recorded against Staphylococcus aureus strains ranging from $0.0062 \mathrm{mg} / \mathrm{ml}$ to $0.05 \mathrm{mg} / \mathrm{ml}$ and $0.097 \mathrm{mg} / \mathrm{ml}$ to $0.19 \mathrm{mg} / \mathrm{ml}$ respectively and for Escherichia coli strains, MIC and MBC values were recorded ranging from 0.062 to $0.31 \mathrm{mg} / \mathrm{ml}$ and $0.0487 \mathrm{mg} / \mathrm{ml}$ to $0.19 \mathrm{mg} / \mathrm{ml}$ respectively.

Synergistic activity of petroleum ether extracts of Syzigium cumini leaf with standard antibiotics ampicillin and against bacteria is shown in Table 5. The combination of petroleum ether extract and ampicillin exhibited synergistic effect on bacterial growth in terms of their MIC and MBC. It was observed alone and combined MIC ranging from 1.56-6.25 mg/ml and $0.19-0.785 \mathrm{mg} / \mathrm{ml}$ against $S$. aureus respectively. MIC ranging from $6.25-25.0 \mathrm{mg} / \mathrm{ml}$ and $0.39-3.12 \mathrm{mg} / \mathrm{ml}$ was recorded against Escherichia coli alone and in combination respectively. Similar trend of synergistic effect was also observed in terms of MBC against both the organisms tested. Combination showed a significant effect against Staphylococcus aureus and Escherichia coli strains.

The first step towards this study was to find out the antibacterial activity of Syzigium cumini leaf extracts against some selected strains of multidrug resistant Staphylococcus aureus and Escherichia coli strains. The extracts of the Syzigium cumini leaf showed significant antimicrobial activity against all tested bacterial strains. Phytochemical studies revealed the presence of various secondary metabolites in the leaf extracts of $S$. cumini. Various phytochemical compounds detected are known to have beneficial importance for human health. The alcohol extract of $S$. cumini was rich in phenols, saponins, glycosides, flavanoids, alkaloids, steroids, terpenoids, resins and tannins. Antibacterial activity of leaf extracts can be attributed due to the presence of these phytochemicals (Cowan, 1999; Padayana et al., 2011). The results of this study support the use of this plant for human diseases and explore the ethnobotanical importance of plant as a potential source of bioactive substances.

The study focuses on antibacterial activity of variety of solvent extracts of $S$. cumini. The present research also observes the sensitivity pattern of selected pathogens towards extracts of $S$. cumini as well as standard antibiotics. In our study, the S. aureus and $E$. coli strains were observed multi drug resistant against the common antibiotics used. (Tiwari et al., 2009). Syzigium cumini extracts showed significant antibacterial activity against almost all bacterial strains tested. Antimicrobial activity of S. cumini was also previously reported by other worker. (Nascimento et al., 2000; Ahmed and Beig, 2001).

In our study the highest zone of inhibition was recorded in petroleum ether leaf extracts of Syzigium cumini against $S$. aureus and E. coli and it was ranged from 8-22 $\mathrm{mm}$ and 12-15 mm respectively which was quite similar with the previous study conducted by Deepak et al., 2014; Yuvraj et al., 2011; Prasad et al., 2013). Our findings are also in agreement with Deepak et al, 2014; Elfadil et al., 2015; Pranoti et al., 2014; Satyawati et al., 2014; Yuvraj et al., 2011 with respect to antimicrobial activity of methanolic extract of Syzigium cumini leaf extract in which the zone of inhibition was reported ranging from 8-20 mm against $S$. aureus and E. coli. Minimum antimicrobial activity was observed in ethyl acetate extract of Syzigium cumini leaves ranging from 8$15 \mathrm{~mm}$ against both $S$. aureus and E. coli strains. Similar observation was also reported by Singh et al., 2016. They also observed the lowest antimicrobial activity in ethyl acetate as compared to other extracts of Syzigium cumini. Prasad et al., 2013 recorded the zone of inhibition with $13 \mathrm{~mm}$ in acetone extract of Syzigium cumini against $S$. aureus which is also similar with our result where zone of inhibition against $S$. aureus was recorded between 8-18 mm. Prasad et al., 2013 reported zone of inhibition in ethanolic extract of Syzigium cumini leaves $(11 \mathrm{~mm})$ against $S$. aureus which is also in agreement of our findings $(8-20 \mathrm{~mm})$ against the MRSA and MSSA. For both Staphylococcus aureus and Escherichia coli strains, MIC and MBC values of Syzigium cumini leaf extracts varied from 1.56 to $25 \mathrm{mg} / \mathrm{ml}$ and 1.56 to 50 $\mathrm{mg} / \mathrm{ml}$ respectively. Our MIC and MBC results of Syzigium cumini leaf extracts are also similar to the other reports. (Chanudom et al., 2014).

The zone of inhibition of chloramphenicol against $S$. aureus was reported $26 \mathrm{~mm}, 21 \mathrm{~mm}$, by Deepak et al., 2014; Yuvraj et al., 2011 respectively which is in agreement with our result in which zone of inhibition against Chloramphenicol was 26-30 $\mathrm{mm}$. 
Table2: Antimicrobial activity of antibiotics against Staphylococcus aureus and Escherichia coli strains.

\begin{tabular}{|c|c|c|c|c|c|c|c|c|c|c|c|c|c|}
\hline \multirow{3}{*}{ S. No. } & \multicolumn{13}{|c|}{ Zone of inhibition(mm) } \\
\hline & \multirow[t]{2}{*}{ Antibiotics } & \multicolumn{6}{|c|}{ Staphylococcus aureus strains } & \multicolumn{6}{|c|}{ Escherichia coli strains } \\
\hline & & SA3 & SA4 & SA10 & SA17 & SA19 & M96 & EC10 & EC11 & EC12 & EC16 & EC17 & MTCC443 \\
\hline 1 & PEN (10 IU) & 20 & - & 28 & 12 & 10 & 28 & - & - & - & - & - & - \\
\hline 2 & $\mathrm{CIP}(5 \mu \mathrm{g})$ & 20 & - & 14 & 12 & 12 & 12 & 16 & 12 & 18 & 14 & - & 14 \\
\hline 3 & KAN $(30 \mu \mathrm{g})$ & 14 & 24 & 18 & 10 & 16 & 16 & 20 & 14 & 14 & 10 & 10 & 11 \\
\hline 4 & AMP $(10 \mu \mathrm{g})$ & - & - & - & - & - & - & - & - & - & - & - & - \\
\hline 5 & ST $(10 \mu \mathrm{g})$ & 16 & 18 & 16 & 12 & 14 & 12 & 18 & 20 & 20 & 22 & 22 & 16 \\
\hline 6 & NR $(100 \mu \mathrm{g})$ & 15 & 18 & 16 & 14 & 12 & 14 & 22 & 18 & 22 & 20 & 20 & 20 \\
\hline 7 & NEO $(30 \mu \mathrm{g})$ & ND & ND & ND & ND & ND & ND & 14 & 16 & 20 & 12 & 20 & 14 \\
\hline 8 & CPD $(30 \mu \mathrm{g})$ & 10 & - & - & - & - & - & - & 10 & 15 & - & - & 12 \\
\hline 9 & $\mathrm{OF}(5 \mu \mathrm{g})$ & 16 & 12 & 10 & - & 12 & - & - & 12 & 12 & 10 & 10 & 11 \\
\hline 10 & TET $(10 \mu \mathrm{g})$ & 14 & 18 & 16 & 12 & 10 & 18 & 20 & 12 & 8 & 12 & 15 & 14 \\
\hline 11 & $\mathrm{SZ}(300 \mu \mathrm{g})$ & - & - & - & - & - & 8 & - & - & - & - & - & - \\
\hline 12 & NA $(30 \mu \mathrm{g})$ & - & - & 8 & 8 & - & - & - & - & - & - & - & - \\
\hline 13 & $\mathrm{CH}(30 \mu \mathrm{g})$ & 26 & 22 & 24 & 24 & 28 & 24 & 22 & 26 & 25 & 22 & 22 & 24 \\
\hline 14 & PB $(300 \mu \mathrm{g})$ & 12 & - & - & 12 & - & 15 & 12 & 12 & - & 15 & 10 & 10 \\
\hline 15 & ERY $(5 \mu \mathrm{g})$ & 10 & 12 & 10 & 8 & 10 & - & - & 10 & - & - & 8 & 12 \\
\hline 16 & AMX $(10 \mu \mathrm{g})$ & 12 & 10 & 12 & 10 & 12 & 16 & - & - & - & - & 12 & 10 \\
\hline 17 & GEN $(50 \mu \mathrm{g})$ & ND & ND & ND & ND & ND & ND & 18 & 20 & 20 & 22 & 22 & 24 \\
\hline 18 & VAN $(30 \mu \mathrm{g})$ & 15 & 17 & 13 & 16 & 16 & 18 & ND & ND & ND & ND & ND & ND \\
\hline 19 & $\operatorname{MET}(5 \mu \mathrm{g})$ & 10 & - & 10 & - & - & 12 & ND & ND & ND & ND & ND & ND \\
\hline 20 & oxacillin $(1 \mu \mathrm{g})$ & 15 & - & 16 & - & - & 16 & ND & ND & ND & ND & ND & ND \\
\hline
\end{tabular}

AM - Amikacin; AP - Ampicillin; CH - Chloramphenicol;; ERY- Erytromycin, GEN - Gentamicin; KAN - Kanamycin; MET - Methicillin; NA - Nalidixic Acid, NR - Nitrofurazone, PEN -Penicillin, SZ - Sulphadiazine, TET - Tetracycline; VAN - Vancomycin , CIP- ciprofloxacin, NEO- neomycin, AMX- amoxicillin, PB- Polymyxin B, NA- Nalidixic acid, OF- Ofloxacin, CPD- cefpodoxime, ST-Streptomycin.

Table 3: Antimicrobial activity of Syzigium cumini extracts in various solvents against clinical strains of Staphylococcus aureus and Escherichia coli.

$$
\text { Zone of inhibition (mm) (Mean } \pm \text { SD) }
$$

\begin{tabular}{|c|c|c|c|c|c|c|c|c|}
\hline \multirow[t]{2}{*}{ Ext } & \multicolumn{6}{|c|}{ Staphylococcus aureus } & \multirow{2}{*}{\multicolumn{2}{|c|}{$\begin{array}{l}\text { p-value } \\
<0.001 *\end{array}$}} \\
\hline & SA3 & $\mathbf{S A} * 4$ & SA10 & $\mathrm{SA}^{* 17}$ & SA*19 & MTCC96 & & \\
\hline $\mathrm{PE}$ & $20.4 \pm 0.95$ & $8.1 \pm 0.75$ & $20.0 \pm 1.32$ & $22.1 \pm 0.6$ & $21.6 \pm 1.10$ & $16.3 \pm 0.40$ & & \\
\hline EA & 0 & $8.1 \pm 0.70$ & $10.3 \pm 0.88$ & $15.3 \pm 0.6$ & $14.0 \pm 0.68$ & $10.0 \pm 0.72$ & & \\
\hline $\mathrm{AC}$ & $8.4 \pm 0.75$ & $10.4 \pm 0.8$ & $15.5 \pm 0.70$ & $18.3 \pm 0.7$ & $16.1 \pm 0.40$ & $18.1 \pm 0.30$ & & \\
\hline ME & $8.1 \pm 0.30$ & 0 & $20.4 \pm 0.85$ & $20.6 \pm 0.9$ & $17.6 \pm 0.75$ & $20.4 \pm 0.88$ & & \\
\hline ET & $10.4 \pm 0.70$ & $8.1 \pm 0.35$ & $20.0 \pm 0.51$ & $10.2 \pm 0.4$ & $12.2 \pm 0.4$ & $10.2 \pm 0.41$ & & \\
\hline DM & 0 & 0 & 0 & 0 & 0 & 0 & & \\
\hline $\mathrm{CH}$ & $28 \pm 1.52$ & $27 \pm 1.50$ & $28.3 \pm 1.05$ & $27.6 \pm 0.5$ & $28.3 \pm 0.66$ & $27.4 \pm 0.60$ & & \\
\hline Ap & 0 & 0 & 0 & 0 & 0 & 0 & & \\
\hline \multicolumn{9}{|c|}{ Zone of inhibition $(\mathrm{mm})($ Mean \pm SD) } \\
\hline \multicolumn{8}{|c|}{ Escherichia coli } & p-value \\
\hline EC10 & \multicolumn{2}{|c|}{ EC11 } & EC12 & EC16 & \multicolumn{2}{|c|}{ EC17 } & M443 & $<0.001 *$ \\
\hline $12.5 \pm 0.7$ & \multicolumn{2}{|c|}{$14.3 \pm 0.6$} & $15.5 \pm 0.9$ & $15.8 \pm 0.6$ & \multicolumn{2}{|c|}{$14.4 \pm 0.6$} & $15.4 \pm 0.9$ & $<0.001 *$ \\
\hline 0 & \multicolumn{2}{|c|}{$8.4 \pm 0.7$} & 0 & 0 & \multicolumn{2}{|c|}{$8.2 \pm 0.15$} & 0 & $<0.001 *$ \\
\hline $16.1 \pm 0.3$ & \multicolumn{2}{|c|}{$17.6 \pm 0.9$} & $15.3 \pm 0.4$ & $20.4 \pm 0.9$ & \multicolumn{2}{|c|}{$22.2 \pm 0.5$} & $18.1 \pm 0.4$ & $<0.001 *$ \\
\hline $20.4 \pm 0.7$ & \multicolumn{2}{|c|}{$19.1 \pm 1.9$} & $20.5 \pm 0.9$ & $15.4 \pm 0.8$ & \multicolumn{2}{|c|}{$15.6 \pm 0.9$} & $18.4 \pm 0.8$ & $<0.001 *$ \\
\hline $22.4 \pm 0.8$ & \multicolumn{2}{|c|}{$20.2 \pm 0.4$} & $24.4 \pm 0.7$ & $10.5 \pm 0.8$ & \multicolumn{2}{|c|}{$10.2 \pm 0.4$} & $20.4 \pm 0.9$ & $<0.001 *$ \\
\hline 0 & \multicolumn{2}{|c|}{0} & 0 & 0 & \multicolumn{2}{|c|}{0} & 0 & 0 \\
\hline $28.4 \pm 0.6$ & \multicolumn{2}{|c|}{$27.9 \pm 0.4$} & $27.4 \pm 1.0$ & $27.8 \pm 0.4$ & \multicolumn{2}{|c|}{$28.5 \pm 0.7$} & $28.1 \pm 0.5$ & $>0.05$ \\
\hline 0 & \multicolumn{2}{|c|}{0} & 0 & 0 & \multicolumn{2}{|c|}{0} & 0 & 0 \\
\hline
\end{tabular}

Data represented as Mean \pm SD. SD: Standard Deviation, ${ }^{*} \mathrm{p}<0.05$, considered statistically significant. Ext $=$ Syzigium cumini leaf extracts, PE $=$ Petroleum ether,

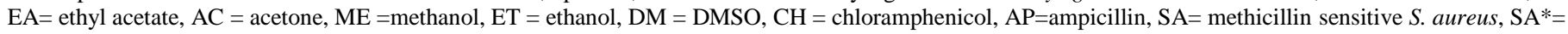
Methicillin resistant $S$. aureus, M443= MTCC reference strain of E. coli, DM= DMSO, EC= Escherichia coli .

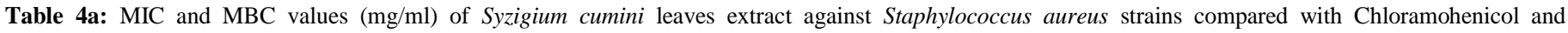
Ampicillin.

\begin{tabular}{|c|c|c|c|c|c|c|c|c|c|c|c|c|}
\hline \multirow{2}{*}{$\begin{array}{l}\text { S. aureus strains } \\
\text { Solvent extracts }\end{array}$} & \multicolumn{2}{|c|}{ SA3 } & \multicolumn{2}{|c|}{$\mathrm{SA} * 4$} & \multicolumn{2}{|c|}{ SA10 } & \multicolumn{2}{|c|}{$\mathbf{S A} * 17$} & \multicolumn{2}{|c|}{$\mathbf{S A} * 19$} & \multicolumn{2}{|c|}{ МТСС 96} \\
\hline & MIC & MBC & MIC & MBC & MIC & MBC & MIC & MBC & MIC & MBC & MIC & MBC \\
\hline Petroleum ether & 3.125 & 6.25 & 1.56 & 3.12 & 1.56 & 3.12 & 6.25 & 6.25 & 1.562 & 3.12 & 1.56 & 3.12 \\
\hline Ethyl acetate & 12.5 & 25.0 & 25.0 & 25.0 & 6.25 & 12.5 & 25.0 & 25.0 & 12.5 & 25.0 & 6.25 & 12.5 \\
\hline Acetone & 3.125 & 6.25 & 6.25 & 12.5 & 3.12 & 6.25 & 6.25 & 12.5 & 12.50 & 12.5 & 1.56 & 3.12 \\
\hline Methanol & 3.125 & 12.5 & 6.25 & 12.5 & 6.25 & 12.5 & 12.5 & 12.5 & 3.125 & 6.25 & 6.25 & 12.5 \\
\hline Ethanol & 6.25 & 12.50 & 12.5 & 25.0 & 3.12 & 6.25 & 12.5 & 25.0 & 6.25 & 6.25 & 3.125 & 6.25 \\
\hline Chloramphenicol & 0.006 & 0.012 & 0.01 & 0.02 & 0.01 & 0.02 & 0.012 & 0.025 & 0.006 & 0.012 & 0.012 & 0.05 \\
\hline Ampicillin & 0.097 & 0.097 & 0.09 & 0.19 & 0.09 & 0.19 & 0.19 & 0.19 & 0.097 & 0.19 & 0.19 & 0.19 \\
\hline
\end{tabular}

MIC and MBC values (mg/ml) of Syzigium cumini leaves extract against Staphylococcus aureus strains compared with chloramohenicol and ampicillin. 
Table 4b: MIC and MBC values (mg/ml) of Syzigium cumini leaves extract against Escherichia coli strains compared with Chloramohenicol and Ampicillin.

\begin{tabular}{|c|c|c|c|c|c|c|c|c|c|c|c|c|}
\hline \multirow[t]{2}{*}{ E. coli strains } & \multicolumn{2}{|c|}{ EC10 } & \multicolumn{2}{|c|}{ EC11 } & \multicolumn{2}{|c|}{ EC12 } & \multicolumn{2}{|c|}{ EC16 } & \multicolumn{2}{|c|}{ EC17 } & \multicolumn{2}{|c|}{ МТСC 443} \\
\hline & MIC & MBC & MIC & MBC & MIC & MBC & MIC & MBC & MIC & MBC & MIC & MBC \\
\hline Pet. ether & 12.5 & 25.0 & 6.25 & 25.0 & 25.0 & 25.0 & 6.25 & 12.5 & 12.5 & 25.0 & 6.25 & 25.0 \\
\hline Ethyl acetate & 25.0 & 50.0 & 12.5 & 25.0 & 25.0 & 50.0 & 12.5 & 12.5 & 6.25 & 12.5 & 12.5 & 25.0 \\
\hline Acetone & 6.25 & 12.5 & 6.25 & 12.5 & 3.12 & 12.5 & 3.12 & 12.5 & 6.25 & 25.0 & 6.25 & 12.5 \\
\hline Methanol & 3.12 & 6.25 & 1.56 & 3.12 & 3.12 & 6.25 & 6.25 & 12.5 & 1.56 & 3.12 & 3.12 & 6.25 \\
\hline Ethanol & 1.56 & 3.12 & 3.12 & 12.5 & 3.12 & 6.25 & 1.56 & 3.12 & 3.12 & 6.25 & 1.56 & 3.12 \\
\hline $\mathrm{CH}$ & 0.06 & 0.12 & 0.12 & 0.12 & 0.03 & 0.06 & 0.15 & 0.31 & 0.03 & 0.06 & 0.06 & 0.12 \\
\hline Ampicillin & 0.04 & 0.09 & 0.09 & 0.19 & 0.09 & 0.19 & 0.09 & 0.19 & 0.04 & 0.19 & 0.04 & 0.09 \\
\hline
\end{tabular}

MIC and MBC values (mg/ml) of Syzigium cumini leaves extract against Escherichia coli strains compared with chloramohenicol and ampicillin.

Table 5: Synergistic effect of Syzigium cumini leaves petroleum ether extracts (SC) with Ampicillin (AP).

\begin{tabular}{|c|c|c|c|c|c|c|c|}
\hline \multirow{3}{*}{ Bacteria } & \multirow{3}{*}{ Strain } & \multicolumn{4}{|c|}{$\begin{array}{l}\text { Extract and antibiotics } \\
\text { (alone) }\end{array}$} & \multicolumn{2}{|c|}{$\begin{array}{c}\text { Extract+Antibiotics } \\
\text { (combination) }\end{array}$} \\
\hline & & \multicolumn{2}{|c|}{ MIC } & \multicolumn{2}{|c|}{ MBC } & \multirow{2}{*}{ MIC } & \multirow{2}{*}{ MBC } \\
\hline & & SC & $\mathbf{A P}$ & SC & $\mathbf{A P}$ & & \\
\hline \multirow{6}{*}{ S.aureus } & SA3 & 3.12 & 0.097 & 6.25 & 0.19 & 0.785 & 1.56 \\
\hline & $\mathrm{SA}^{*} 4$ & 1.56 & 0.097 & 3.12 & 0.19 & 0.195 & 0.39 \\
\hline & SA10 & 1.56 & 0.097 & 3.12 & 0.19 & 0.195 & 0.78 \\
\hline & $\mathrm{SA}^{*} 17$ & 6.25 & 0.195 & 12.5 & 0.39 & 0.785 & 1.56 \\
\hline & SA*19 & 1.56 & 0.097 & 3.12 & 0.19 & 0.195 & 0.78 \\
\hline & МТ96 & 1.56 & 0.195 & 3.12 & 0.39 & 0.39 & 0.39 \\
\hline \multirow{6}{*}{ E. coli } & EC10 & 12.5 & 0.048 & 25.0 & 0.096 & 1.56 & 3.12 \\
\hline & EC11 & 6.25 & 0.097 & 25.0 & 0.19 & 0.39 & 3.12 \\
\hline & $\mathrm{EC} 12$ & 25.0 & 0.097 & 50.0 & 0.19 & 3.12 & 6.25 \\
\hline & $\mathrm{EC} 16$ & 6.25 & 0.097 & 12.5 & 0.19 & 0.39 & 0.78 \\
\hline & $\mathrm{EC} 17$ & 12.5 & 0.048 & 25.0 & 0.096 & 3.12 & 3.12 \\
\hline & M443 & 6.25 & 0.048 & 25.0 & 0.096 & 0.78 & 3.12 \\
\hline
\end{tabular}

MT 96= MTCC 96, M 443= MTCC 443, all values are expressed in $\mathrm{mg} / \mathrm{ml} . \mathrm{SA}=$ S. aureus, $\mathrm{EC}=$ E. coli, *= Methicillin resistant $S$. aureus.

MIC of ampicillin was recorded against $S$. aureus was $0.097-0.19 \mathrm{mg} / \mathrm{ml}$ which is in agreement with Bonyadi et al. (MIC of ampicillin against $S$. aureus was $0.048 \mathrm{mg} / \mathrm{ml})$. The zone of inhibition and minimum bactericidal concentration $(\mathrm{MBC})$ are two different attributes and there is no linear relationship between zone of inhibition and MBC.

Combined therapy has been justified to decrease the bacterial resistance and produce a desirable significant synergistic effect (Esimone et al., 2006). Antibiotic synergism with bioactive plant extracts is useful in treating infectious diseases.

In our study, synergistic effect was verified resulting from the combination of ampicillin with petroleum ether extracts of Syzigium cumini. Our results are in agreement with the other studies which reported synergistic effects with significant reduction in the MICs of the antibiotics in combination with different crude plant extracts against drug resistant bacteria (Esimone et al., 2006; Braga et al., 2005; Sibanda and Okok, 2007). It was observed a significant increase in activity of ampicillin when combined with tested plant extract (Table 5). Combinations of two or more compounds are generally superior to the use of a single compound, especially for the treatment of infections caused by drug resistant bacteria.

\section{CONCLUSION}

Our study certifies that the extract of Syzigium cumini has a significant potential antimicrobial activity against the multidrug resistant bacteria and also serves an important data regarding the valuable research in treating infectious diseases. It also reveals that the petroleum ether may be an effective solvent in future for antimicrobial studies of Syzigium cumini. The research data are also comparable with the common antibiotics used against S. aureus and Escherichia coli.

A considerable synergism was also obtained between the Syzigium cumini and antibiotics used against $S$. aureus and Escherichia coli, so Syzigium cumini may be an effective alternative of antibiotics in the treatment of infectious diseases.

\section{ACKNOWLEDGEMENTS}

The authors are thankful to Prof. S. W. Akhtar, Vice Chancellor, Integral University, for providing the BRTF and necessary facility to conduct this research work and Manuscript communication number (MCN) - IU/R\&D/2017-MCN 00019. The authors are also thankful to UGC, Govt. of India, for providing Maulana Azad National Fellowship to Mohammed Imran (Senior Research Fellow) and grateful to the Laboratory in charge of Era's Lucknow Medical College and Hospital and IIMSR Lucknow, for providing the clinical samples and their cooperation with regard the research work.

Conflict of Interest: We declare that we have no conflict of interest. 


\section{REFERENCES}

Ahmad I, Beg AZ. Antimicrobial and phytochemical studies on 45 Indian medicinal plants against multi-drug resistant human pathogens. Journal of Ethnopharmacology, 2001; 74: 113-123

Ahmad, I., Mehmood, Z., Mohammad, F., 1998. Screening of some Indian medicinal plants for their antimicrobial properties. Journal of Ethnopharmacology 62, 183-193.

Akram, M, Shahid M, Khan AU. Etiology and antibiotics resistance pattern of community acquired urinary infections in $\mathrm{J} \mathrm{N} \mathrm{M} \mathrm{C}$ Hospital Aligarh India. Ann. Clin Microbiol. Antimicrob, 2007; 6, 4.

Bauer AW, Kirby WMN, Sherris JC. Antibiotic susceptibility testing by standardized single disc method. Am. J. Clin. Pathol. 1966; 45:493-496.

Bonyadi RE, Vital A and Bipinraj NK. Antimicrobial activity of the ethanolic extract of Bryonopsis laciniosa leaf, stem, fruit and seed. African Journal of Biotechnology, 2009; 8 (15): 3565-3567,

Braga LC, Leite AM, Xavier KGS, Takahashi JA, Bemquerer MP, Chartone-Souza E, Nascimento MA. Synergic interaction between pomegranate extracts and antibiotics against Staphylococcus aureus. Can. J. Microbiol. 2005, 51:541-547.

Chanda S, Dudhatra S, Kaneria M. Antioxidative and antibacterial effects of seeds and fruit rind of nutraceutical plants belonging to the family Fabaceae family. Food and Function, 2010; 1:308315 .

Chanudom L, Bhoopong P, Khwanchuea R and Tangpong J. Antioxidant and antimicrobial activities of aqueous \& ethanol crude extracts of 13 Thai traditional plants. Int. J. Curr. Microbiol. App. Sci, 2014; 3(1): 549-558.

Chopra RN, Nayer SL, Chopra IC. Glossary of Indian Medicinal Plants. Council of Scientific and Industrial Research, New Delhi, 1992; 3:7-246.

CLSI (Clinical and Laboratory Standards Institute) 2010. Performance Standards for Antimicrobial Susceptibility Testing; 20th Informational Supplement, Clinical and Laboratory Standards Institute Wayne, PA: M100-S20: 30(1).

Cowan MM. Plant products as antimicrobial agents. Clin. Microbiol. Rev. 1999; 12: 564-582.

Dabur R, Singh H, Chhillar AK, Ali M, Sharma GL. Antifungal potential of Indian medicinal plants. Fitoterapia, s2004; 75(3-4): 389-391.

Deepak k, Arora S, Alam M. Pharmacognostical standardization and antimicrobial activity of leaves of Syzigium cumini (Linn.) from various region of North India. Int. Res. J. Pharm. 2014; 5(2): 62-65.

Elfadil AG, Awad AK, Ahmed MA, Abed AH, Sabahelkhier M.K. Antimicrobial activities of Syzygium cumini leave extracts against selected microorganisms. Nova Journal of Medical and Biological Sciences, 2015; 4(2):1-8.

Eloff JN. Sensitive and quick microplate method to determine the minimum inhibitory concentration of plant extracts for bacteria. Planta Med, 1998; 64:711-713.

Esimone CO, Iroha IR, Ibezim EC, Okeh CO, Okpana EM. In vitro evaluation of the interaction between tea extracts and penicillin $\mathrm{G}$ against Staphylococcus aureus. Afr. J. Biotechnol, 2006; 5: 1082-1086.

Gislene G.F, Locatelli NJ, Paulo CF, Giuliana LS. Antibacterial activity of plant extracts and phytochemicals on antibiotic resistant bacteria. Braz. J. Microbiol, 2000; 31: 247-256.

Gowri SS.Vasantha K. Phytochemical screening and antibacterial activity of Syzygium cumini L leaves extracts. International Journol of pharm Tech reaserch, 2010; 2:1569-1573.

Habbal O, Hasson SS, El-Hag AH, Al-Mahrooqi Z, Al-Hashmi N, Al-Bimani Z, Al-Balushi MS, Al-Jabri AA. Antibacterial activity of Lawsonia inermis linn (Henna) against Pseudomonas aeruginosa. Asian Pacific Journal of Tropical Biomedicine, 2011; 1:173-176.
Harbottle $\mathrm{H}$, Thakur S, Zhao S, White DG. Genetics of antimicrobial resistance. Anim. Biotechnol, 2006; 17: 111-124.

Khan AU, Musharraf A. Plasmid mediated multiple antibiotic resistances in Proteus mirabilis isolated from patients with urinary tract infection. Med. Sci. Mont, 2004; 10: 598-602.

Mehmood, Z., Ahmad, I., Mohammad, F., Ahmad, S., 1999. Indian medicinal plants: A potential source of anticandidal drugs. Pharmaceutical Biology 37, 237-242.

Mohanta B, Chakraborty A, Sudarshan M, Dutta RK, Baruah M. Elemental profile in some common medicinal plants of India. Its correlation with traditional therapeutic usage. Journal of Radio analytical, Nuclear Chemistry, 2003; 258: 175-179.

Mulligen M.E, Murry-Leisure KA, Ribner BS, Standiford HC, John JF, Karvick JA, Kauffman C.A, Yu VL. Methicillin resistant Staphylococcus aureus. American Journal of Medicine, 1993; 94: 313 328.

Padayana S, Ashalatha M, Prajna PS, Yende A, Bhatt R. Evaluation of antibacterial and antioxidant properties of Uvaria narum (Dunal) Wall. Int. Research J. Pharm. 2011; 2(5): 142-144.

Parekh J, Chanda SV. In vitro antimicrobial activity and phytochemical analysis of some Indian medicinal plants. Turkish J Biol, 2007; 31:53-8

Perez C, Pauli M, Bazerque P. An antibiotic assay by the well agar method. Acta Biologiae et Medicine Experimentalis, 1990; 15:113115.

Pranoti B, goyal P. Invitro evaluation of phytochemical and antioxidant properties of Syzigium cumini leaves and their synergistic effect on its antimicrobial property. Int. J. Res. Pharm. Sci, 2014;5(4): 254-258.

Prasad B. Kailas D, Waghmere R. Antibacterial activity of Vulgarol A extracted from the leaves of Syzigium cumini. Asian J Pharm Clin Res, 2013; 6(4) :100-102.

Satyavathi C, Bhavani NL. Evaluation of phytochemical constituents and antibacterial activity in leaf extracts of Syzigium cumini $L$. 2014; 3(10): 768-776.

Sibanda T, Okok AI. The challenges of overcoming antibiotic resistance: Plant extracts as potential sources of antimicrobial and resistance modifying agents. Afr. J. Biotechnol., 2007; 6: 2886-2896.

Singh K, Kaur R, Kaur AP. Studies on antioxidant and antimicrobial potential of Syzygium cumini leaves. Research Journal of Pharmaceutical, Biological and Chemical Sciences, 2016; 7(2): 677-682.

Tiwari HK, Das AK, Sapkota D, Sivarajan K, Pahwa VK. Methicillin resistant Staphylococcus aureus: Prevalence and antibiogramin a tertiary care hospital in western Nepal. J. Infect. Dev. Ctries, 2009; 3:681-68.

Yang ZC, Wang BC, Yang XS, Wang Q, Ran L. The synergistic activity of antibiotics combined with eight traditional Chinese medicines against two different strains of Staphylococcus aureus. Colloids Surf B Biointerfaces, 2005; 41: 79-81.

Yuvraj M, Kadtan K, Wakte P. Antimicrobial potential of Syzygium cumini L. Journal of Pharmacy Research, 2011; 4(8): 2784-2786.

\section{How to cite this article:}

Imran M, Imran M, Khan S. Antibacterial activity of Syzigium cumini leaf extracts against multidrug resistant pathogenic bacteria. J App Pharm Sci, 2017; 7 (03): 168-174. 